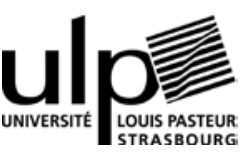

Laboratoire de Recherche en Gestion \& Economie

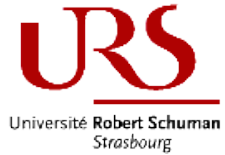

Strasbourg

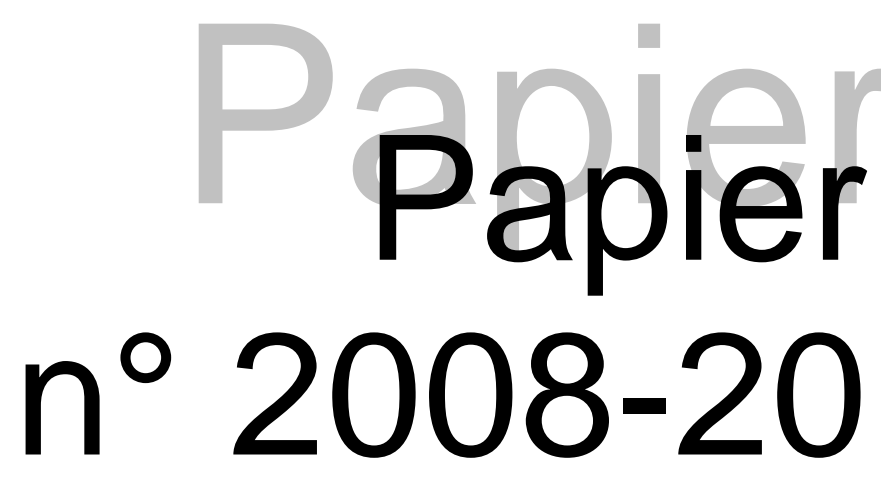

Duration of syndication process and syndicate organization

Christophe J. Godlewski

Faculté des

Novembre 2008

sciences économiques

et de gestion

PEGE

61, avenue de la Forêt Noire 67085 STRASBOURG Cedex

Tél. : (33) 0390242152

Fax : (33) 0390242064

www-ulp.u-strasbg.fr/large

Institut d'Etudes Politiques

47, avenue de la Forêt Noire 67082 STRASBOURG Cedex 


\title{
Duration of syndication process and syndicate organization $^{1}$
}

\author{
Christophe J. Godlewski \\ University of Strasbourg - LaRGE \& EM Strasbourg Business School ${ }^{2}$ \\ Last revised: November 2008
}

\footnotetext{
${ }^{1}$ I thank Marie-Hélène Broihanne, Drew Dahl, Fabian Gleisner, Kurt Hess, Jean-Charles Rochet, Razvan Vlahu, Laurent Weill, and the participants of the AFFI Conference 2008, Lille, France; the FMA European Conference 2008, Prague, Czech Republic; the 25th Symposium on Money, Banking and Finance 2008, Luxembourg, for their comments, remarks, and suggestions on a previous version of the paper. The usual disclaimer applies.

${ }^{2}$ PEGE, 61 avenue de la Forêt Noire, 67000 Strasbourg, France. Tel. + 33 (0)3.90.24.21.21 / Fax + 33 (0)3.90.24.20.64. E-mail: godlewski@cournot.ustrasbg.fr.
} 


\begin{abstract}
What is the influence of syndicate organization on the duration of a loan syndication process? We answer this question using the survival analysis methodology on a sample of loans to borrowers from 59 countries. We find that syndicate size, concentration, experience, reputation, and national diversity clearly matters for the duration of a syndication process and therefore for borrower satisfaction regarding the speed of obtaining the necessary funding. A syndicate organization adapted to specific agency problems of syndication, with numerous, reputable, and experienced arrangers retaining a larger portion of the loan reduces the duration. The latter is also shorter when more lenders come from the same country as the borrower. These effects are more pronounced when the borrower has a low reputation on the syndicated lending market and when his opacity is stronger.
\end{abstract}

Keywords : Syndicated loan, syndication process, syndicate organization, agency costs, experience, reputation, nationality, survival analysis.

JEL Classification : F30, G15, G21, G32, C41. 


\section{Introduction}

This articles investigates the influence of the organizational characteristics of a banks syndicate, such as size, concentration, and reputation, on the duration of a loan syndication process, i.e. the time between the launching of the syndication until the completion date, when the deal becomes active. This duration is considered as the critical stage of the transaction cycle for a syndicated loan (Rhodes, 2004). Therefore, it is an important criteria of choice for the borrowers to apply for a syndicated loan ${ }^{1}$, as the speed of obtaining the necessary funding is considered to be a significant advantage of syndicated lending compared to bonds or a series of bilateral loans ${ }^{2}$.

However, syndicated lending has also its drawbacks because it implies specific agency problems due to informational frictions between the members of the syndicate. Following the theoretical work of Pichler and Wilhelm (2001), recent empirical evidence shows that an adapted organizational structure of the syndicate is a crucial feature to mitigate syndication agency costs (Lee and Mullineaux, 2004; Jones et al., 2005; Sufi, 2007). Indeed, a small and concentrated syndicate, with arrangers retaining a large portion of the loan, allows for a better monitoring of an opaque borrower and can signal its quality. Such organization mitigates also free-riding and hold-up within the syndicate, while the presence of experienced and reputable arrangers enhances screening and monitoring of the borrower and acts as a certification device of his quality.

Therefore, syndicate organization has an important influence on the pricing of syndicated loans (Harjoto et al., 2006; Ivashina, 2008; Focarelli et al., 2008), borrower's wealth (Preece and Mullineaux, 1996), and liquidity risk management (Gatev and Strahan, 2008). Furthermore, the presence of established and reputable lenders provides substantial advantages to the borrowers

\footnotetext{
${ }^{1} \mathrm{~A}$ syndicated loan is a loan defined by a single agreement in which several banks participate.

${ }^{2}$ Other advantages of syndicated lending for lenders and borrowers are portfolio and sources of income diversification and more competitive pricing and more flexible funding structure respectively. These benefits can explain the the impressive development of the syndicated lending, as the funds raised on this market represent more than one third of the funds raised on the worldwide financial markets (Altunbas et al., 2005).
} 
(Gopalan et al., 2007; Ross, 2007; Panyagometh and Roberts, 2008). Overall, the organization of a syndicate matters for the borrower, as it influences loan terms and wealth.

However, the influence of syndicate organization on the duration of the syndication process seems neglected in existing academic literature ${ }^{3}$. This is surprising for two reasons. First, informational problems that raise syndication specific agency problems can interfere with efficient and fast decision making (Kocher and Sutter, 2006; Schulte and Gruner, 2007). Second, empirical evidence shows that the organizational structure of teams have a significant impact on the speed of decision making (Eisenhardt, 1989; Talaulicar et al., 2005). Hence, a syndicate organization which is supposed to be adapted to syndicate specific agency problems should also play an important role in the syndication process duration.

This duration is of particular interest for the borrower for evident reasons related to the speed of obtaining the funds. For that reason, one of the main arguments driving the choice of a bank that will arrange the syndication is his speed of action. The arranger is the key figure of a syndication because he is the privileged agent in the relationship between the borrower and the syndicate. Thus, he is responsible for a crucial feature of an efficient and successful loan syndication: the syndicate organization.

The aim of this article is to investigate the influence of syndicate organization on the duration of a syndication process. Indeed, it is particularly relevant to empirically document if syndicate organization influences this duration, and which characteristics are the most important to guarantee the shortest syndication process. Such evidence is valuable for borrowers, because their satisfaction is increasing with fast and efficient syndication, as well as lenders, because their reputation is contingent on the duration of the syndication process. Finally, empirical evidence on the relationship between syndicate organization and duration of syndication process adds to the growing literature on syndicated lending.

To test the influence of syndicate organization on the duration of the

\footnotetext{
${ }^{3}$ Godlewski (2008) provides a broad empirical investigation of factors driving the duration of a syndication process.
} 
syndication process, we employ accelerated failure time models on a sample of more than 4, 800 syndicated loans for borrowers from 59 countries during the $1992-2006$ period. We use various measures of syndicate organization, such as size, concentration, experience and reputation, and composition.

We find that syndicate organization clearly matters for syndication process duration. The latter can be significantly reduced provided a larger number of arrangers, who retain larger shares of the loan, and are more reputable and experienced players on the syndicated lending market. These characteristics become even more critical when the borrower has a low reputation on the syndicated lending market or when he is more opaque. Furthermore, the duration is shorter when an important share of lenders in the syndicate are from the same country as the borrower, as well as when a large percentage of lenders within the syndicate are themselves from the same country. However, when the loan is syndicated to a borrower from an emerging market, the presence of reputable international arrangers matters more for a quick syndication process.

The rest of the article is organized as follows. Section 2 presents the loan syndication process and discusses the arguments linking syndication specific agency problems and syndicate organization to the syndication process duration. Section 3 is devoted to the discussion of various measures of syndicate organization. Section 4 presents the data and the accelerated failure time model methodology. Results are displayed and discussed in section 5. Section 6 provides our conclusions.

\section{Loan syndication process and syndicate or- ganization}

This section is devoted to the description of a typical loan syndication process which duration is the central issue of this article. We also discuss arguments linking agency problems and syndicate organization to the syndication process duration. 


\subsection{Loan syndication process}

Bank loan syndication can be considered as a sequential process, which can be separated into three main stages ${ }^{4}$ : the pre-mandated stage during which the details of the proposed transaction are discussed and finalized, the postmandated stage during which the syndication itself takes place and facility agreements are negotiated, and the operational post-signing stage.

More precisely, during the pre-mandated stage, after soliciting competitive offers to arrange and manage the syndication with one or more banks (usually its main banks) $^{5}$, the borrower chooses one or more arrangers that are mandated to form a syndicate and negotiates a preliminary loan agreement. The syndication can be sole or joint mandated, the latter involving the participation of more than one lead bank ${ }^{6}$. The arranger is responsible for the negotiation of key loan terms with the borrower, the appointment of participants ${ }^{7}$ and the structuring of the syndicate. His compensation is mainly composed of various fees (agency, arrangement, commitment, ... ).

The post-mandated stage involves the placement of the loan. This stage is considered as crucial for the transaction cycle of a syndication. Indeed, both the borrower and the arrangers have committed themselves to raise funds and are therefore at risk. During this stage, the arranger prepares a documentation package for the potential syndicate members, called an information memorandum. It usually contains information about borrower creditworthiness and loan terms. The initial set of targeted participants is strongly determined by the arranger. Their previous experience with the borrower, the industry sector or the geographic area are strong drivers for being

\footnotetext{
${ }^{4}$ See Esty (2001); Rhodes (2004); Taylor and Sansone (2007) for a detailed presentation of the syndicated lending process.

${ }^{5}$ Principal milestones before the submission of a bid by banks are the identification and articulation of the borrower's need from the syndicated credit market, the decision on a bidding configuration and strategy by the banks, and the internal approval of the credit by the potential arrangers.

${ }^{6}$ Such syndications are usually chosen by the borrower in order to maximize the likelihood of a successful syndication, in terms of loan characteristics, subscription and duration of the syndication process.

${ }^{7}$ Participants lend a portion of the loan and receive a compensation essentially composed of a spread.
} 
chosen by the arranger to join the syndicate. A roadshow is then organized to present and discuss the content of the information memorandum, as well as to announce closing fees and establish a timetable for commitments and closing. The participants can make comments and suggestions in order to influence the structure and the pricing of the loan. After the roadshow, the arranger makes formal invitations to potential participants and determines the allocation given to each participant.

The post-signing stage takes place after the completion date when the deal becomes active and the loan is operational, binding the borrower and the syndicate members by the debt contract $^{8}$.

\subsection{Agency problems, syndicate organization, and syn- dication process duration}

Loan syndication involves several actors - the arrangers, the participants and the borrower - and is a complex process involving specific agency costs. The latter are the consequence of informational frictions within the syndicate which can harm efficient and fast decision making (Kocher and Sutter, 2006; Schulte and Gruner, 2007), and thus can interfere with the benefits of syndicated loan, both for the borrower and the lenders, mitigating the intrinsic advantages of this source of funds for firms. However, these costs can be reduced through an adapted organization of the syndicate, which can ultimately influence the duration of the syndication process. Indeed, as shown by Eisenhardt (1989); Talaulicar et al. (2005), team organization has a significant influence on the speed of decision making.

Syndication-specific agency problems are of two types. First, the arranger possesses more information about the borrower either because of the private information collected through a previous lending relationship or through due diligence. This private information creates an adverse selection problem as the arranger may be inclined to syndicate loans to bad borrowers. Second,

\footnotetext{
${ }^{8}$ The contract sets out the terms and conditions of the loan: the amount, the purpose, the period, the rate of interest plus any fees, the periodicity and the design of repayments and the presence of any security.
} 
the participant banks may delegate some monitoring tasks to the arranger. This may result in a moral hazard problem as the efforts of the lead bank are unobservable for participant banks. These agency problems can be mitigated by an adequate organization of the syndicate.

Indeed, the presence of numerous arrangers can reduce adverse selection problems related to private information (Lee and Mullineaux, 2004; Jones et al., 2005; Sufi, 2007). It is likely that some of the arrangers will act as specialized agents during the syndication, thus resulting in a better handling of the process, with increased cost efficiency and reduced informational asymmetry (François and Missionier-Piera, 2007). Greater concentration of the portions of the loan retained by the arrangers is more suited to cope with free-riding and moral hazard problems, as well as with hold-up problems in case of borrower's distress and subsequent reorganization and renegotiation (Esty and Megginson, 2003). Furthermore, arrangers' retained share of the loan provides a signal of their commitment to efficiently monitor the borrower and can also be considered as a device to align lenders' incentives within the syndicate and to signal borrower's quality (Lee and Mullineaux, 2004; Sufi, 2007). As syndicates with numerous arrangers retaining significant portions of the loan mitigate agency costs of syndication, we expect such syndicate structures to have a negative influence on the syndication process duration.

As the arrangers are responsible for due diligence, allocation of the loan to other syndicate members, and ex post monitoring, banks in the syndicate will often rely on the leaders reputation in making lending decisions (Ross, 2007). Therefore, reputation is an important aspect for syndicated lending (Gopalan et al., 2007). Indeed, reputable and experienced leaders can enhance monitoring and ability to attract participants, signal borrower and deal quality, and reduce agency costs (Ross, 2007; Gatti et al., 2008; Panyagometh and Roberts, 2008). Furthermore, certification by experienced, reputable, and prestigious arrangers creates economic value by reducing overall costs of syndicated loans. Hence, we expect that the presence of experienced and reputable arrangers in the syndicate should reduce the syndication process duration.

Finally, recent evidence by Carey et al. (1998) and Hao (2004) shows 
that lenders identity matters for bank lending. Furthermore, Tykvova and Schertler (2008) show that physical distance between borrowers and lenders influences information-related transaction costs, which are important drivers of successful syndication. Moreover, previous experience in the geographic area is an important driver for choosing syndicate members by the arranger, in order to mitigate informational frictions regarding the borrower as well as between the lenders of the syndicate (Champagne and Kryzanowski, 2007; Sufi, 2007). Therefore, we expect the syndicate composition in terms of lenders' nationality to have an impact on the duration of the syndication process. However, the sign of this effect remains a matter of empirical tests. A syndicate with more lenders from the same country as the borrower should enhance better knowledge of the latter thus reducing informational frictions within the syndicate and the duration of the syndication process. Better trust and understanding can also be achieved when more lenders within the syndicate are from the same country, but such a syndication composition can also generate collusion risk, exacerbate agency costs, and thus increase the syndication process duration.

To summarize, as syndicate organization can be considered as a response to specific agency problems of loan syndication, it should also influence the duration of the syndication process which is sensitive to agency costs.

\section{Empirical design}

In this section we describe the syndicate organization variables and their expected influence on the syndication process duration. We also present loan and country control variables used in the regressions. Table 1 provides the definitions of all variables used in this article.

\subsection{Syndicate organization variables}

The key figures of a syndicate are the number of arrangers and the concentration of the shares of the loan retained by the arrangers. The concentration is measured by the normalized Herfindhal-Hirschman Index of the shares of 
the loan retained by the arrangers (Concentration of arrangers) ${ }^{9}$. The size of the syndicate corresponds to the number of arrangers in the syndicate (Number of arrangers). We expect both of these measures to have a negative influence on the syndication process duration. A larger syndicate "core" with greater retained portions of the loan implies better handling of agency problems related to monitoring of the borrower as several delegated monitors are present. Furthermore, greater concentration can signal a borrower with better quality.

We also consider experience and reputation measures in the syndicate, which bring a certification device regarding the quality of the borrower and of the loan. Top 10 arrangers (presence) and Top 10 arrangers (market) are variables based on the percentage of the arrangers in the syndicate who are in the top 10-th percentile distribution of the most frequent arrangers and of the arrangers having the greatest market shares of the syndicated lending market respectively ${ }^{10}$. League table arrangers is based on the percentage of the arrangers in the syndicate who are listed on the Loan Pricing Corporation (Reuters) Global League Table ${ }^{11}$. The distinction between presence and market share provides a more detailed insight into the importance of being on the market versus having greater shares of the market (the "dominant bank effect", Ross, 2007). Experience, skills and reputation can be acquired through more intense participation in deals but also through less participation but greater stakes of syndicated loans. Being listed on a League Table is a strong signal of arranger's quality and market reputation. For all these reasons, we expect a negative impact of these measures on the syndication process duration.

\footnotetext{
${ }^{9} \mathrm{An}$ alternative variable is the share of the loan retained by the arranger (or the mean share if there are several arrangers) but we experience convergence problems when estimating the model with this alternative variable. Nevertheless, the latter is strongly correlated with the Concentration of arrangers variable in our sample.

${ }^{10}$ Details regarding the computation of these measures can be found in table 1 . The median value of arrangers participation in loan syndications equals 4 , while the top 10-th percentile equals 55 . The median value of arrangers market share in the syndicated lending market equals 0.00016, while the top 10-th percentile equals 0.00107 . There are 78 top 10 arrangers who are the most present and 61 top 10 arrangers who have the greatest market share.

${ }^{11}$ The list of arrangers from the Global League Table is provided in table 1.
} 
We also use several measures of the composition of the syndicate with a particular focus on the nationality of the lenders. We compute the percentage of lenders in the syndicate that are from the same country as the borrower, differentiating lenders regarding their titles (and thus their ranks), and classifying them into three categories ${ }^{12}$ : top (i.e. leaders of the syndicate), mid (i.e. managers of the syndicate), and low (i.e. participants of the syndicate) lenders. We also measure the percentage of lenders classified as low and top, as well as low and mid, who are from the same country. Here, we focus on the titles of the lenders and we consider them as signals of their importance in the hierarchy of the syndicate ${ }^{13}$.

This leads to four additional variables labeled Same country top lenders, Same country mid lenders, Same country mid-low lenders, and Same country top-low lenders ${ }^{14}$. The sign and magnitude of these measures are relatively unclear. On the one hand, greater percentage of lenders from the same country as the borrower, whatever their position in the syndicate hierarchy, should reduce the duration. Indeed, information sharing can be more efficient if the lenders come from the same country. This helps to overcome important informational frictions within the syndicate, regarding both the members and the borrower. Furthermore, comparative advantages in terms of financing and information sharing are expected to grow with such syndicate composition, i.e. where lenders are from the same country.

On the other hand, a greater proximity between top lenders and the borrower may exacerbate adverse selection problems, if the informational gain of the top lenders is not shared with other lenders. It is plausible that a greater percentage of top and low lenders from the same country might exacerbate potential informational problems from the "syndicate managers" perspective and thus increase agency costs of syndication, and in consequence slow down the duration of the syndication process. It might also exacerbate potential

\footnotetext{
${ }^{12}$ Classification of lenders is described in table 1.

${ }^{13}$ The aggregation of the titles into three categories is based on Rhodes (2004) and Taylor and Sansone (2007).

${ }^{14}$ We do not use other measures such as the percentage of low lenders in the syndicate who are from the same country as the borrower because such percentage is usually very close to 100 percent. For the same reasons, we do not use the percentage of low and mid lenders who are from the same country within the syndicate.
} 
collusive behavior of these type of lenders and enhance the expropriation risk of other lenders. In case of borrower's distress, such composition can leave the other lenders with unsatisfactory solutions. Hence, we can observe a positive influence of these variables on the syndication process duration.

\subsection{Loan and country control variables}

Following Dennis and Mullineaux (2000); Esty and Megginson (2003); Lee and Mullineaux (2004); Sufi (2007); Godlewski and Weill (2008), we take main loan characteristics such as the logarithm of loan size (Loan size), lenders' compensation (Spread and Fee), loan maturity (Maturity), presence of a guarantor (Guarantors), covenants (Covenants), and debt seniority (Senior debt) into account. To control for the impact of publicly available information, we include a dummy variable $S \mathscr{E} P$ Rating equal to one if a Standard and Poor's senior debt rating is available. We also control for the type and purpose of the loan, benchmark rate, facility issue year, geographical area, and industry. In order to take legal risk into account, we include the protection of creditor rights (Creditor Rights) and law enforcement (Rule of Law) indexes provided by Djankov et al. (2007) and LaPorta et al. (1998).

\section{Data and methodology}

We first present the sample and descriptive statistics. Then, the econometric methodology employed to investigate the determinants of the syndication process duration is exposed.

\subsection{Data and descriptive statistics}

Information on the duration of syndication process, syndicate organization, and loan characteristics come from the Dealscan database, provided by the Loan Pricing Corporation (Reuters). Data concerning country characteristics come from LaPorta et al. (1998), and Djankov et al. (2007).

The sample size is determined by information availability on the endogenous and exogenous variables used in the regressions. The endogenous vari- 
able is the syndication process duration, measured in days since the launching date until the completion date, when the deal becomes active. We use only completed syndicated loans and eliminate the outliers for the endogenous variable : deals with duration greater than the 99-percentile, equal to 243 days (above 8 months). Therefore, we obtain a sample of 4, 807 syndicated loans from 59 countries for the period between 1992 and 2006.

Descriptive statistics can be found in table 1, while the distribution of the number of loans, and lenders-tranches and mean syndication process duration by country are displayed in table 2 .

We observe that the mean of a syndication process duration equals 55.14 days (almost 8 weeks) with a standard deviation of 37.02 days. We also remark that emerging market borrowers have the largest durations, sometimes above 100 days in the Czech Republic, Oman and Venezuela. Borrowers from these countries represent a significant part of our sample, while banks from Western Europe and North America represent a majority of the lenders. On these markets, the presence of experienced arrangers is the most important,

as Top 10 arrangers (presence) and Top 10 arrangers (market) equal to $70 \%$ and $7 \%$ respectively. The maximum average for league table arrangers can also be found in North America (26\%). On the contrary, the average values of these syndicate organization measures are the lowest in emerging markets, for instance less than $50 \%$ and $1 \%$ respectively for Top 10 arrangers (presence) and Top 10 arrangers (market) in Eastern Europe. The minimum average for League table arrangers is for Latin America (12\%). A similar frontier between industrialized and emerging markets exist for the measures of syndicate composition in terms of lenders' nationality. For instance, the average value of Same country top lenders equals 30\% in Western Europe and $22 \%$ in Latin America.

\subsection{Econometric specification}

Since the dependent variable is the duration of a syndication process, the appropriate methodology is survival analysis which is used to analyze data in which the time until the event is of interest, called an event time. 
Survival data are generally described and modeled in terms of two related functions ${ }^{15}$, namely the survival and hazard functions respectively. Let $T$ represent the duration of time that passes before the occurrence of a certain random event. Here $T$ is the syndication process duration and $S(t)$ the survival probability that the syndication process lasts from the time origin (launching date) to a future time $t$, and is defined as

$$
S(t)=\operatorname{Prob}(T \geq t)=1-F(t)
$$

where $F(t)$ is the cumulative distribution function for $T$.

The hazard is usually denoted by $h(t)$ (also called instantaneous event rate) and is the rate of transition of the syndicated process duration to completion, given it has not been completed before. The hazard function is defined formally by

$$
h(t)=\lim _{\Delta t \rightarrow 0} \frac{\operatorname{Prob}(t \leq T<t+\Delta t \mid T \geq t)}{\Delta t}=\frac{f(t)}{S(t)},
$$

where $f(t)$ is the probability density function of $T$ evaluated at $t$. Since $\frac{\delta S(t)}{\delta t}=-f(t)$, the hazard function can be expressed as

$$
h(t)=-\frac{\delta \log S(t)}{\delta t}
$$

the negative of the slope of the log of the survival function.

When estimating hazard functions, we need to assume a hazard function specification. The latter can use parametric survival models known as accelerated failure time (AFT) models ${ }^{16}$. An AFT model specifies that the predictors act multiplicatively on the event time or additively on the log of event time. The effect of a predictor is to alter the rate at which the syndication process proceeds along time axis.

\footnotetext{
${ }^{15}$ See Kiefer (1988) and Harrell (2001) for a detailed description of survival analysis.

${ }^{16}$ Another possibility is to use the proportional hazards $(\mathrm{PH})$ model, where $h(t)=$ $h_{0}(t) \exp \left(X^{\prime} \beta\right)$, given the predictors $X$ and the baseline hazard rate $h_{0}(t)$. The latter can be left unspecified and estimated using the Cox's semiparametric partial likelihood (Cox, 1972, 1975) or take a specific parametric form such as Weibull or exponential distributions. Within this approach, the hazards are supposed to be proportional over time. This assumption is strongly rejected in our case.
} 
In this framework, the logarithm of the survival time $\log (t)$ is expressed as a linear function of the covariates $X$ :

$$
\log (t)=\alpha+X^{\prime} \beta+\epsilon
$$

where $\alpha$ is the intercept and $\epsilon$ is the error term with density $f(t)$. The distributional form of the error term determines the regression model ${ }^{17}$. The hazard function in an AFT model takes the form

$$
h(t)=h_{0} \exp \left(\alpha+X^{\prime} \beta\right)\left(\exp \left(\alpha+X^{\prime} \beta\right) t\right),
$$

where $h_{0}$ is the baseline hazard rate. The hazard function is estimated using maximum likelihood methods.

\section{Results and discussion}

In this section, we present and discuss the estimations results and provide some robustness checks. First, we provide estimate results for specifications with syndicate size, concentration, experience, and reputation measures only. Second, we discuss the results obtained with syndicate composition measures only. Third, we provide results including both type of measures in the regressions. Fourth, we discuss results regarding the effect of borrower reputation and opacity on the relationship between syndication organization and syndication process duration. Fifth, we focus on emerging markets borrower effects on the syndicate organization and syndication process duration. Finally, we present several robustness checks.

\footnotetext{
${ }^{17}$ With normal, logistic, extreme-value and three-parameter gamma density functions, we obtain respectively log-normal, log-logistic, Weibull and generalized gamma regressions.
} 


\subsection{Influence of syndicate size, concentration, experi- ence, and reputation on syndication process dura- tion}

As the proportional hazard assumption is strongly rejected by Schoenfled residuals tests, we estimate an AFT model assuming a generalized gamma distribution, as the latter provides the lowest log likelihood, as well as Akaike and Schwarz information criterions. Results are displayed in table 3.

First of all, most of the variables of interest exhibit statistically significant coefficients, suggesting that syndicate organization has an economic impact on syndication process duration.

As expected, a greater number of arrangers and their concentration significantly reduces the syndication process duration. We remark that the coefficient for Concentration of arrangers is much greater than for Number of arrangers, suggesting that the former organizational characteristic of a syndicate matters more for quicker syndication process. A greater percentage of experienced and reputable arrangers also significantly reduces the syndication process. Greater percentage of experienced arrangers having important market shares matters more for quick syndication process as the coefficient for Top 10 arrangers (market) is the greatest among the measures of experience and reputation.

What seems to really matter for a quick and thus efficient loan syndication process is the presence of experienced arrangers on the syndicated lending market and the concentration of arrangers rather than the presence of frequent or reputable players on the syndicated lending market. Indeed, arrangers retaining significant shares of the loan or having acquired significant experience through the arrangement of large syndicated deals provides an important signal regarding the quality of the borrower and of the deal, as well as of the arranger, and thus allows to provide funds more quickly. 


\subsection{Influence of syndicate composition on syndication process duration}

We now turn to the discussion of the results obtained with syndicate composition measures only, displayed in table 4. Most of the variables exhibit statistically significant coefficients, suggesting that syndicate composition has an economic impact on loan syndication process duration ${ }^{18}$.

The arguments on potential collusion problems seem to be validated as Same country top lenders exhibit positive coefficients, while Same country mid lenders has a negative influence on the duration. Within syndicate composition also has a significant impact on duration, as Same country midlow lenders bears a negative coefficient sign.

As top lenders are usually borrower relationship banks or established institutions on the syndicated lending market, they usually have access to privileged information, that might be used against other members of the syndicate. This can exacerbate agency costs and thus make the syndication process last longer. This adverse effect of Same country top lenders is somehow mitigated when taking Same country mid lenders into account, but still remains. A greater percentage of syndicate "managers" from the same country reduces the duration as the coefficient exhibit a significantly negative sign. Finally, a greater percentage of close mid and low lenders in terms of nationality significantly reduces the duration due to better information sharing between "managers" and participants. The greatest coefficient and thus the most important economic effect is for the Same country top lenders variable, although it makes the duration of the syndication process last longer.

\subsection{Influence of syndicate size, experience, reputation, and composition on syndication process duration}

Now we include all types of syndicate organization measures in the regressions to get a deeper insight into the main syndicate design features that drives

\footnotetext{
${ }^{18}$ Due to the correlation structure, Same country mid-low lenders and Same country top-low lenders cannot be included in the same regression.
} 
the syndication process duration. Results are displayed in table $5^{19}$.

Results remain robust, as all coefficients for the syndicate organization variables remain significant and with the same signs as in tables 3 and 4 . Syndicate size, experience, and reputation are always significantly negative with similar magnitude of coefficients, while syndicate composition variables exhibit same coefficients as in table 4 , but their values are affected. This is particularly the case in the regression with Number of arrangers, where the coefficients of Same country top lenders and Same country mid lenders gain between 0.07 and 0.09, while Same country mid-low lenders and Same country top-low lenders gain more than 0.20. This suggests that syndicate composition effect on syndication process duration is reinforced when taking syndicate size into account. Indeed, syndicate composition should play a greater role when the syndicate size is larger. This effect is far less pronounced when looking at the coefficients for Top 10 arrangers and syndication composition. In that case, the latter have even lower magnitude when compared to those in table 4.

Overall, conclusions drawn from the results obtained in tables 3 and 4 remain. Syndicate organization matters for syndication process duration, which can be significantly reduced provided arrangers retaining larger shares of the loan, and having more experience on the syndicated lending market. Furthermore, a greater geographic closeness in terms of nationality between the "managers" of the syndicate and the borrower is also beneficial for quick syndication process. This is also achieved when "managers" and participants come from the same country.

\subsection{Borrower reputation and opacity effects}

We investigate more deeply the effect of borrower reputation and opacity on the relationship between syndication process duration and syndicate organization. Indeed, previous results, i.e. the importance of concentration,

\footnotetext{
${ }^{19}$ We do not display results with the Concentration of arrangers variable because of convergence problems when estimating the model with this variable and syndicate composition measures. Although not displayed due to lack of space, coefficients for loan and country control variables remain overall unchanged compared to results in tables 3 and 4 .
} 
experience and geographical closeness of the members of the syndicate, should be even more pronounced if the borrower has acquired less reputation on the syndicated loan market or when he is more opaque. Indeed, lending to such borrowers is more exposed to informational problems and to agency problems within the syndicate.

Borrower reputation is computed using the number of different arrangers that have arranged a deal for a particular borrower in our sample. Indeed, a borrower who has been funded with syndicated loans arranged by various arrangers acquires valuable reputation on the syndicated lending market, as more arrangers have a better knowledge regarding his business and risk profile, as well as his financing needs. More precisely, for each borrower we compute the number of interactions (or links) that he had with a different arranger for a deal in the sample ${ }^{20}$. Then, we use the median of that measure, equal to 8 , to classify the borrowers as having low reputation if their number of interactions is lower than 8. We consider as opaque a borrower who is not listed on a stock exchange. Public firms are usually considered as being more transparent compared to private ones.

Results are displayed in tables 6 and $7^{21}$ for the borrower reputation and opacity influences respectively. When comparing to our base results in tables 3 and 4 , we remark several important modifications of the coefficients. The most striking ones concern the increase of the coefficient for Concentration of arrangers in table 6 , which gains 0.13 , and the lack of significance for Top 10 arrangers (market). Apparently, lack of borrower reputation reinforces the role of arrangers retained shares concentration which serves as a signal of efficient screening and monitoring of the borrower as well as his quality. Arrangers experience plays no significant role in that case. Regarding the syndicate composition measures, we also observe significant changes. First, the presence of "managers" geographically close to the borrower vanishes away

\footnotetext{
${ }^{20}$ The mean of the number of interactions (or links) equals 11.08 with a standard deviation of 12.69. This means that an average borrower had 11 interactions with different arrangers in the sample.

${ }^{21}$ We experienced convergence problems for the regressions with Number of arrangers and Concentration of arrangers and we cannot provide estimation results for these two specifications for opaque borrowers.
} 
the effect of Same country top lenders, while potential collusive effects are now present on the top-low lenders level, as the latter coefficient is significant and positive.

In table 7, the effect of arrangers experience is strongly reinforced as the coefficient of Top 10 arrangers (market) gains 0.38 compared to table 3 and appears as being crucial for opaque borrowers getting syndicated loans quickly. Thus, borrower opacity seems to have a different effect compared to his reputation. Furthermore, the collusive effect of top lenders being from the same country as the borrower is stronger, as the coefficients gain between 0.08 and 0.10 . It seems that borrower opacity leaves more room for potential collusive behavior within the syndicate.

Overall, borrower characteristics such as reputation and opacity matters for syndication process duration, as syndicate organization features such as arrangers retained shares concentration or experience become much more critical when the borrower has a low reputation or is more opaque.

\subsection{Emerging markets borrower effect}

As a significant part of the loans in our sample are provided to borrowers from emerging markets, we investigate if this feature has an impact on our results. Indeed, as shown by Nini (2004), the presence of a domestic participant in a syndicated loan to borrowers in developing economies has a significant and negative impact on the cost of funds, because the presence of a local lender from these markets, considered as more opaque than industrialized economies, reduces informational problems within the syndicate. However, domestic lenders usually lack of necessary competence, expertise, know-how, knowledge, experience and reputation regarding syndicated lending (Tykvova and Schertler, 2008). This might explain the presence of several arrangers, with domestic ones reducing informational and relational problems, and the international ones bringing their experience and reputation. Thus, it is possible that syndicates lending to emerging markets borrowers have specific features adapted to such problems and might influence differently the syndication process duration. 
In our sample, the average number of arrangers is greater for deals arranged for emerging markets borrowers (7.8) as compared to non emerging markets deals (4.67). Furthermore, the average percentage of top lenders from the same country as the borrower is lower for emerging market borrowers than for industrialized ones $(21.08 \% \text { versus } 37.05 \%)^{22}$. These significantly different syndicate structures translate in a difference of 8 days only regarding the average syndication process duration for emerging versus industrialized market borrowers ${ }^{23}$.

When regressing the syndication process duration on the presence of league table arrangers and of same country top lenders for a sub-sample of deals syndicated for emerging market borrowers, we find no significant coefficient for the latter variable, while the former is significant and negative. League table arrangers coefficient gains 0.18 in that case as compared to the coefficient in specification (1.5a) in table 5. Hence, even if the syndicates lending to borrowers from emerging markets are different in terms of organization, we do not find any empirical evidence on the added value of local lenders presence regarding informational problems with respect to the syndication process duration. What matters for quick syndication process duration is the presence of reputable international arrangers with the necessary expertise and knowledge in arranging the deals.

\subsection{Robustness checks}

We have performed several robustness checks regarding the use of alternative variables, bounding the endogenous variable, and applying other estimation methods and procedures.

When performing the regressions on a reduced sample with elimination of syndication process durations over 100 and 200 days respectively does not alter the results. Coefficients remain significant with the same signs, although their magnitude is reduced. Using more restrictive definitions to compute the

\footnotetext{
${ }^{22}$ We also observe a similar difference regarding league table arrangers (17.65\% in emerging markets vs $23.94 \%$ in industrialized markets).

${ }^{23}$ The average durations for emerging and non emerging market borrowers equal 50.73 and 42.21 days respectively.
} 
Top arrangers measures as well as Same country top lenders gives very similar results $^{24}$. Furthermore, when considering the frequency of the borrower's presence on the syndicate lending market as an alternative measure of his reputation ${ }^{25}$ gives virtually similar results, although the magnitude of the coefficients are reduced.

For all the estimations obtained with a gamma model, the magnitude and the significance of the covariates are similar to those obtained with Weibull, log-logistic and log-normal models. We have also followed a two-step procedure in order to address the potential endogeneity issue between the duration and the syndicate organization ${ }^{26}$. In the first step, using OLS we regress the various syndicate organization measures on the loan characteristics already used in the estimations. In the second step, using an AFT model with gamma distribution we regress the syndication process duration on the fitted syndicate organization measures from step one. Results from step two are similar to those already obtained regarding the coefficients significance and sign.

Overall, results regarding the influence of syndicate organization on syndication process duration hold after surviving several robustness checks.

\section{Conclusion}

Informational problems that raise syndication specific agency problems can interfere with efficient and fast decision making (Kocher and Sutter, 2006; Schulte and Gruner, 2007). Following Pichler and Wilhelm (2001), empirical evidence supports the argument that an adapted organizational structure of the syndicate is a crucial feature to mitigate these agency problems (Lee and Mullineaux, 2004; Jones et al., 2005; Sufi, 2007). This organizational structure of the banking team may have a significant impact on the speed

\footnotetext{
${ }^{24}$ Alternative definitions implied considering agent, arranger, bookrunner, lead arranger, lead bank, mandated arranger, and senior arranger titles only, or agent, arranger, bookrunner, mandated arranger titles only.

${ }^{25}$ In that case, we simply count the number of times a particular borrower is funded by a syndicated loan in the sample to compute his frequency of presence on the market.

${ }^{26}$ In order to not overload the paper we do not provide these results but they are available upon request.
} 
of decision making (Eisenhardt, 1989; Talaulicar et al., 2005). Therefore, a syndicate organization which is supposed to be adapted to syndicate specific agency problems, should also have an important influence on the syndication process duration.

Using a sample of more than 4,800 syndicated loans to borrowers from 59 countries for the $1992-2006$ period, we have employed accelerated failure time models to test the influence of the syndicate organization on the loan syndication process duration, measured in days since the syndication launching date until the completion date when the loan contract is signed. This stage of a transaction cycle for a syndicated loan is considered as the most critical because both the borrower and the arrangers are at risk (Rhodes, 2004). We measure syndicate organization with various characteristics related to syndicate size, concentration, experience, reputation and composition.

Empirical results show that syndicate organization clearly matters for syndication process duration. In particular, arrangers' retained loan shares concentration and experience are crucial inputs allowing to significantly speed up the syndication process and thus providing the borrower with necessary funds in a shorter amount of time. Indeed, these two main features provide an efficient signal regarding the handling of the syndication process, of the agency problems, and of the borrower quality. They become even more critical when the borrower has a low reputation on the syndicated lending market or when he is more opaque.

Furthermore, the duration is shorter when an important share of "managers" in the syndicate are from the same country as the borrower, as well as when a large percentage of participants and "managers" come from the same country. This result receives an interpretation related to the reduction of informational frictions within the syndicate when such composition is at work. However, the presence of local arrangers has no significant impact on the duration when the loan is syndicated to a borrower from an emerging market. In that case, what really matters for quick syndication process is the presence of reputable international arrangers.

Overall, the syndication process duration can be significantly reduced 
provided a larger number of arrangers, who retain larger shares of the loan, and are more reputable and experienced players on the syndicated lending market. These are the most important features to be taken into account by the borrower if his main interest is for short syndication process duration in order to access the necessary funds quickly. Thus, the syndicate organization is an important input for corporate finance decisions and should be carefully analyzed by the borrower but also by the lenders. Finally, these results contribute to the existing literature on the importance of syndicate organization for successful and value enhancing loan syndication. 


\section{References}

Altunbas, Y., Gadanecz, B., Kara, A., 2005. Key factors affecting internationally active banks' decisions to participate in loan syndications. Applied Economic Letters 12, 249-253.

Carey, M., Post, M., Sharpe, S., 1998. Does corporate lending by banks and finance companies differ? evidence on specialization in private debt contracting. Journal of Finance 53, 845-878.

Champagne, C., Kryzanowski, L., 2007. Are current syndicated loan alliances related to past alliances? Journal of Banking and Finance 31, 3145-3161.

Cox, D., 1972. Regression models and life tables. Journal of the Royal Statistical Society 24, 187-201.

Cox, D., 1975. Partial likelihood. Biometrika 62, 269-276.

Dennis, S., Mullineaux, D., 2000. Syndicated loans. Journal of Financial Intermediation 9, 404-426.

Djankov, S., McLiesh, C., Shleifer, A., 2007. Private credit in 129 countries. Journal of Financial Economics 84, 299-329.

Eisenhardt, K. M., 1989. Making fast strategic decisions in high-velocity environments. The Academy of Management Journal 32, 543-576.

Esty, B., 2001. Structuring loan syndicates: A case study of the hong kong disneyland project loan. Journal of Applied Corporate Finance 14, 80-95.

Esty, B., Megginson, W., 2003. Creditor rights, enforcement, and debt ownership structure: Evidence from the global syndicated loan market. Journal of Financial and Quantitative Analysis 38, 37-59.

Focarelli, D., Pozzolo, A., Casolaro, L., 2008. The pricing effect of certification on syndicated loans. Journal of Monetary Economics 55, 335-349.

François, P., Missionier-Piera, F., 2007. The agency structure of loan syndicates. The Financial Review 42, 227-245.

Gatev, E., Strahan, P., 2008. Liquidity risk and syndicate structure. Journal of Financial Economics (forthcoming).

Gatti, S., Kleimeier, S., Megginson, W., Steffanoni, A., 2008. Arranger certification in project finance. Working paper. 
Godlewski, C., 2008. Handbook of Credit Portfolio Management. Gregoriou and Hoppe, McGraw-Hill, Ch. What Drives the Arrangement Timetable of Bank Loan Syndication?

Godlewski, C., Weill, L., 2008. Syndicated loans in emerging markets. Emerging Markets Review 9, 206-219.

Gopalan, R., Nanda, V., Yerramilli, V., 2007. Lead arranger reputation and the loan syndication market. Working paper.

Hao, L., 2004. Bank effects and the determinants of loan yield spreads. Working paper.

Harjoto, M., Mullineaux, D., Yi, H.-C., 2006. A comparison of syndicated loan pricing at investment and commercial banks. Financial Management $35,49-70$.

Harrell, F., 2001. Regression Modeling Strategies With Applications to Linear Models, Logistic Regression, and Survival Analysis. Springer Series in Statistics.

Ivashina, V., 2008. Asymmetric information effects on loan spreads. Journal of Financial Economics (forthcoming).

Jones, J., Lang, W. W., Nigro, P. J., 2005. Agent behavior in bank loan syndications. Journal of Financial Research 28, 385-402.

Kiefer, N., 1988. Econometric duration data and hazard functions. Journal of Economic Literature 25, 646-679.

Kocher, M., Sutter, M., 2006. Time is money-time pressure, incentives, and the quality of decision-making. Journal of Economic Behavior and Organization $61,375-392$.

LaPorta, R., de Silanes, F. L., Shleifer, A., 1998. Law and finance. Journal of Political Economy 106, 1113-1155.

Lee, S., Mullineaux, D., 2004. Monitoring, financial distress, and the structure of commercial lending syndicates. Financial Management 33, 107-130.

Nini, G., 2004. The value of financial intermediaries: Empirical evidence from syndicated loans to emerging market borrowers. International Finance Discussion Paper 820, FRB. 
Panyagometh, K., Roberts, G., 2008. Do lead banks exploit syndicate participants? evidence from ex post risk. Financial Management (forthcoming).

Pichler, P., Wilhelm, W., 2001. A theory of the syndicate: Form follows function. Journal of Finance 56, 2237-2264.

Preece, D., Mullineaux, D., 1996. Monitoring, loan renegotiability, and firm value: The role of lending syndicates. Journal of Banking and Finance 20, $577-593$.

Rhodes, T., 2004. Syndicated Lending Practice and Document. Euromoney Books.

Ross, D., 2007. The "dominant bank effect": How high lender reputation affects the information content and terms of bank loans'. Working paper.

Schulte, E., Gruner, H., 2007. Speed and quality of collective decision making: Imperfect information processing. Journal of Economic Theory 134, 138154.

Sufi, A., 2007. Information asymmetry and financing arrangements: Evidence from syndicated loans. Journal of Finance 62, 629-668.

Talaulicar, T., Grundei, J., v.Werder, A., 2005. Strategic decision making in start-ups: the effect of top management team organization and processes on speed and comprehensiveness. Journal of Business Venturing 20, 519541.

Taylor, A., Sansone, A., 2007. The Handbook of Loan Syndications and Trading. McGraw-Hill.

Tykvova, T., Schertler, A., 2008. Syndication to overcome transaction costs of cross-border investments? evidence from a worldwide private equity deals' dataset. Working paper. 
Table 1: Variables definition and descriptive statistics

The table provides a brief description and descriptive statistics for variables used in the regressions, with a distinction of loan, syndicate organization, and country characteristics, as well as control variables. Loan, syndicate organization and control variables come from Dealscan (LPC, Reuters). Country characteristics come from LaPorta et al. (1998); Djankov et al. (2007).

\begin{tabular}{|c|c|c|c|c|}
\hline Variable & Description & $\mathrm{N}$ & Mean & Std. dev. \\
\hline \multicolumn{5}{|c|}{ Loan characteristics } \\
\hline $\begin{array}{l}\text { Syndication } \\
\text { process dura- } \\
\text { tion }\end{array}$ & $\begin{array}{l}\text { Duration of the loan syndication process since } \\
\text { the launching date until the completion date, } \\
\text { measured in days. }\end{array}$ & 4807 & 55.1367 & 37.0186 \\
\hline Loan size & $\begin{array}{l}\text { Logarithm of the size of the loan (in million } \\
\text { USD). }\end{array}$ & 4807 & 18.5816 & 1.3801 \\
\hline Spread & Spread over the benchmark rate (in bps). & 4807 & 110.6984 & 79.8330 \\
\hline Fee & Up front fee (in bps). & 4807 & 52.6986 & 43.6978 \\
\hline Maturity & Maturity of the loan (in months). & 4807 & 53.8417 & 36.0990 \\
\hline Guarantors & $=1$ if there is at least one guarantor. & 4807 & 0.0957 & 0.2942 \\
\hline Covenants & $\begin{array}{l}=1 \text { if the loan agreement includes financial } \\
\text { covenants. }\end{array}$ & 4807 & 0.1157 & 0.3199 \\
\hline Senior debt & $=1$ if the debt is senior. & 4807 & 0.2528 & 0.4346 \\
\hline $\mathrm{S} \& \mathrm{P}$ rating & $\begin{array}{l}=1 \text { if the borrower has a senior debt rating } \\
\text { by Standard \& Poor's. }\end{array}$ & 4807 & 0.0616 & 0.2404 \\
\hline Term loan & $=1$ if the loan is a term loan. & 4807 & 0.5891 & 0.4920 \\
\hline $\begin{array}{l}\text { Corporate pur- } \\
\text { poses }\end{array}$ & $\begin{array}{l}=1 \text { if the loan purpose is general corporate } \\
\text { purposes funding. }\end{array}$ & 4807 & 0.1059 & 0.3077 \\
\hline Debt repayment & $\begin{array}{l}=1 \text { if the loan purpose is debt repayment } \\
\text { funding. }\end{array}$ & 4807 & 0.1949 & 0.3962 \\
\hline Working capital & $\begin{array}{l}=1 \text { if the loan purpose is working capital } \\
\text { funding. }\end{array}$ & 4807 & 0.0786 & 0.2692 \\
\hline Project finance & $\begin{array}{l}=1 \text { if the loan purpose is project finance } \\
\text { funding. }\end{array}$ & 4807 & 0.1009 & 0.3012 \\
\hline Libor & $=1$ if the benchmark rate is the Libor. & 4807 & 0.2592 & 0.4382 \\
\hline Euribor & $=1$ if the benchmark rate is the Euribor. & 4807 & 0.0811 & 0.2731 \\
\hline \multicolumn{5}{|c|}{ Syndicate organization characteristics } \\
\hline $\begin{array}{l}\text { Number of ar- } \\
\text { rangers }\end{array}$ & Number of arrangers in the syndicate. & 4807 & 3.6004 & 3.6992 \\
\hline $\begin{array}{l}\text { Concentration } \\
\text { of arrangers }\end{array}$ & $\begin{array}{l}\text { Normalized Herfindhal-Hirschman Index of } \\
\text { the loan shares retained by arrangers. }\end{array}$ & 4530 & 0.2443 & 0.2409 \\
\hline
\end{tabular}


Table 1: (continued)

\begin{tabular}{|c|c|c|c|c|}
\hline Variable & Description & $\mathrm{N}$ & Mean & Std. dev. \\
\hline $\begin{array}{l}\text { Top } 10 \quad \text { ar- } \\
\text { rangers } \\
\text { (presence) }^{1}\end{array}$ & $\begin{array}{l}\text { Percentage of the syndicate arrangers in the } \\
\text { top 10-th centile of the most frequent ar- } \\
\text { rangers in the sample. }\end{array}$ & 4530 & 0.6925 & 0.2085 \\
\hline $\begin{array}{l}\text { Top } 10 \quad \text { ar- } \\
\text { rangers } \\
(\text { market })^{2}\end{array}$ & $\begin{array}{l}\text { Percentage of the syndicate arrangers in the } \\
\text { top 10-th centile regarding market share of } \\
\text { syndicated loans in the sample. }\end{array}$ & 4530 & 0.0684 & 0.1391 \\
\hline $\begin{array}{l}\text { League table } \\
\text { arrangers }^{3}\end{array}$ & $\begin{array}{l}\text { Percentage of the syndicate arrangers in the } \\
\text { Loan Pricing Corporate (Reuters) Global } \\
\text { League Table in the sample. }\end{array}$ & 4530 & 0.2146 & 0.1676 \\
\hline $\begin{array}{l}\text { Same country } \\
\text { top lenders }\end{array}$ & $\begin{array}{l}\text { Percentage of the syndicate 'top lenders' } \\
\text { from the same country as the borrower. }\end{array}$ & 4530 & 0.3078 & 0.2295 \\
\hline $\begin{array}{l}\text { Same country } \\
\text { mid lenders }\end{array}$ & $\begin{array}{l}\text { Percentage of the syndicate 'mid lenders' } \\
\text { from the same country as the borrower. }\end{array}$ & 4530 & 0.9199 & 0.1288 \\
\hline $\begin{array}{l}\text { Same country } \\
\text { mid-low lenders }\end{array}$ & $\begin{array}{l}\text { Percentage of the syndicate 'mid' and 'low' } \\
\text { lenders from the same country. }\end{array}$ & 4530 & 0.8554 & 0.1748 \\
\hline $\begin{array}{l}\text { Same country } \\
\text { top-low lenders }\end{array}$ & $\begin{array}{l}\text { Percentage of the syndicate 'top' and 'low' } \\
\text { lenders from the same country. }\end{array}$ & 4530 & 0.0917 & 0.1365 \\
\hline \multicolumn{5}{|c|}{ Country characteristics } \\
\hline Creditor rights & $\begin{array}{l}\text { An index aggregating four aspects of cred- } \\
\text { itor rights. The index ranges from zero } \\
\text { (weak creditor rights) to four (strong credi- } \\
\text { tor rights) }\end{array}$ & 3782 & 2.7343 & 0.9635 \\
\hline Rule of law & $\begin{array}{l}\text { An index indicating the law enforcement. } \\
\text { The index ranges from zero (weak enforce- } \\
\text { ment) to ten (strong enforcement) }\end{array}$ & 4245 & 6.9136 & 2.0854 \\
\hline
\end{tabular}

${ }^{1}$ : We count the number of times a particular arranger participates in a syndicated loan in the sample and we use the 90-th percentile of its distribution to distinguish top arrangers for participation intensity. Then we compute the percentage of such top arrangers in a syndicate for every deal.

2: We compute for each arranger the sum of all syndicated loans shares funded per year and we divide this number by the sum of syndicated loans per year in the sample. We use the 90-th percentile of the distribution of this variable to distinguish top arrangers for market shares. Then we compute the percentage of these arrangers in a syndicate for every deal.

3: LPC (Reuters) Global League Table arrangers are: Bank of America, Barclays, BNP Paribas, Calyon, Citigroup, ING, JP Morgan, Mitsubishi Financial, Royal Bank of Scotland, Sumitomo Mitsui Banking.

4: Lenders are classified as 'top' if they bear the following titles in the syndicate: administrative agent, agent, arranger, bookrunner, lead arranger, mandated arranger, senior arranger, underwriter, lead bank, joint arranger, managing agent, senior managing agent, syndication agent, co-agent, co-arranger, senior co-arranger, sub-underwriter, co-lead arranger, co-syndication agent, co-underwriter.

5: Lenders are classified as 'mid' if they bear the following titles in the syndicate: lead manager, senior lead manager, co-lead manager, expanded lead manager, senior co-lead manager, manager, co-manager, senior manager.

6: Lenders are classified as 'low' if they bear the following titles in the syndicate: participant, lender, senior lender. 
Table 2: Distribution of the number of loans and lenderstranches, and mean syndication process duration by country

The table provides the number of loans and lenders-tranches, as well as respective in sample frequency, by country, as well as mean values of the endogenous variable Syndication process duration by borrower country.

\begin{tabular}{|c|c|c|c|c|c|}
\hline Country & $\begin{array}{r}\text { Number of } \\
\text { loans }\end{array}$ & Freq. & $\begin{array}{r}\text { Syndication process } \\
\text { duration }\end{array}$ & $\begin{array}{r}\text { Number of } \\
\text { lenders-tranches }\end{array}$ & Freq. \\
\hline Argentina & - & - & - & 10 & 0.03 \\
\hline Australia & 172 & 3.58 & 63.61 & 158 & 0.55 \\
\hline Austria & 3 & 0.06 & 51.33 & 924 & 3.21 \\
\hline Bahrain & 11 & 0.23 & 37.81 & 297 & 1.03 \\
\hline Belgium & 21 & 0.44 & 49.52 & 744 & 2.59 \\
\hline Bermuda & 2 & 0.04 & 56.00 & - & - \\
\hline Bulgaria & 2 & 0.04 & 43.00 & - & - \\
\hline Canada & - & - & - & 543 & 1.89 \\
\hline Cayman Islands & 10 & 0.21 & 48.00 & - & - \\
\hline China & 350 & 7.28 & 59.99 & 101 & 0.35 \\
\hline Croatia & 10 & 0.21 & 46.20 & 16 & 0.06 \\
\hline Cyprus & - & - & - & 16 & 0.06 \\
\hline Czech Republic & 2 & 0.04 & 125.00 & 56 & 0.19 \\
\hline Denmark & 10 & 0.21 & 54.3 & 325 & 1.13 \\
\hline Egypt & 7 & 0.15 & 53.00 & 86 & 0.30 \\
\hline Finland & 14 & 0.29 & 39.28 & 167 & 0.58 \\
\hline France & 167 & 3.47 & 52.31 & 3894 & 13.54 \\
\hline Germany & 117 & 2.43 & 53.06 & 4819 & 16.76 \\
\hline Ghana & 3 & 0.06 & 45.33 & - & - \\
\hline Greece & 7 & 0.15 & 63.00 & 168 & 0.58 \\
\hline Hong Kong & 759 & 15.79 & 51.38 & 409 & 1.42 \\
\hline Hungary & 21 & 0.44 & 50.57 & 154 & 0.54 \\
\hline Iceland & 4 & 0.08 & 41.25 & 19 & 0.07 \\
\hline India & 190 & 3.95 & 56.45 & 48 & 0.17 \\
\hline Indonesia & 525 & 10.92 & 61.49 & 30 & 0.10 \\
\hline Iran & - & - & - & 35 & 0.12 \\
\hline Ireland & 5 & 0.10 & 45.00 & 319 & 1.11 \\
\hline Israel & - & - & - & 74 & 0.26 \\
\hline Italy & 47 & 0.98 & 51.95 & 1593 & 5.54 \\
\hline Japan & 57 & 1.19 & 47.26 & 1906 & 6.63 \\
\hline Jordan & - & - & - & 119 & 0.41 \\
\hline Kazakhstan & 5 & 0.10 & 32.00 & - & - \\
\hline Korea (South) & 616 & 12.81 & 32.74 & 44 & 0.15 \\
\hline Kuwait & 2 & 0.04 & 64.00 & 182 & 0.63 \\
\hline Latvia & - & - & - & 22 & 0.08 \\
\hline
\end{tabular}


Table 2: (continued)

\begin{tabular}{|c|c|c|c|c|c|}
\hline Country & $\begin{array}{r}\text { Number of } \\
\text { loans }\end{array}$ & Freq. & $\begin{array}{r}\text { Syndication process } \\
\text { duration }\end{array}$ & $\begin{array}{r}\text { Number of } \\
\text { lenders-tranches }\end{array}$ & Freq. \\
\hline Luxembourg & 14 & 0.29 & 68.85 & 334 & 1.16 \\
\hline Malaysia & 151 & 3.14 & 70.10 & 22 & 0.08 \\
\hline Malta & - & - & - & 15 & 0.05 \\
\hline Morocco & - & - & - & 16 & 0.06 \\
\hline Netherlands & 61 & 1.27 & 57.57 & 2034 & 7.07 \\
\hline New Zealand & 28 & 0.58 & 57.07 & - & - \\
\hline Norway & 20 & 0.42 & 42.10 & 303 & 1.05 \\
\hline Oman & 5 & 0.10 & 116.80 & 90 & 0.31 \\
\hline Pakistan & 19 & 0.40 & 38.47 & 14 & 0.05 \\
\hline Papua New Guinea & 5 & 0.10 & 93.60 & - & - \\
\hline Philippines & 115 & 2.39 & 69.23 & - & - \\
\hline Poland & 17 & 0.35 & 65.82 & 111 & 0.39 \\
\hline Portugal & 15 & 0.31 & 40.53 & 288 & 1.00 \\
\hline Qatar & 6 & 0.12 & 80.83 & 107 & 0.37 \\
\hline Romania & 8 & 0.17 & 47.15 & 21 & 0.07 \\
\hline Russian Federation & 31 & 0.64 & 50.48 & 44 & 0.15 \\
\hline Saudi Arabia & 4 & 0.08 & 18.50 & 187 & 0.65 \\
\hline Singapore & 155 & 3.22 & 54.66 & 72 & 0.25 \\
\hline Slovakia & 2 & 0.04 & 50.50 & 37 & 0.13 \\
\hline Slovenia & 9 & 0.19 & 43.33 & 13 & 0.05 \\
\hline South Africa & 21 & 0.44 & 47.95 & 74 & 0.26 \\
\hline Spain & 30 & 0.62 & 46.76 & 489 & 1.70 \\
\hline Sri Lanka & 3 & 0.06 & 38.33 & - & - \\
\hline Sweden & 26 & 0.54 & 47.65 & 327 & 1.14 \\
\hline Switzerland & 14 & 0.29 & 43.57 & 396 & 1.38 \\
\hline Taiwan & 293 & 6.10 & 86.01 & 200 & 0.70 \\
\hline Thailand & 395 & 8.22 & 56.29 & - & - \\
\hline Tunisia & 3 & 0.06 & 48.00 & 36 & 0.13 \\
\hline Turkey & 21 & 0.44 & 31.71 & 65 & 0.23 \\
\hline United Arab Emirates & 6 & 0.12 & 56.66 & 296 & 1.03 \\
\hline United Kingdom & 165 & 3.43 & 51.57 & 2701 & 9.39 \\
\hline United States of America & - & - & - & 3047 & 10.60 \\
\hline Venezuela & 3 & 0.06 & 113.66 & - & - \\
\hline Vietnam & 14 & 0.29 & 77.92 & - & - \\
\hline
\end{tabular}


Table 3: Estimation results with syndicate size, experience, concentration, and reputation measures only

The table provides estimation results of the accelerated failure time model with a gamma distribution for different specifications (1.1 to 1.5) in terms of syndicate organization measures. The dependent variable is Syndication process duration. Definition of variables appear in table 1. Robust standard errors in parentheses. ${ }^{* * *},{ }^{* *},{ }^{*}$ correspond to coefficients significantly different from 0 at $1 \%, 5 \%$ and $10 \%$ level. Loan type, loan purpose, benchmark rate, facility active year, industry and geographical areas dummies included but not reported.

\begin{tabular}{|c|c|c|c|c|c|}
\hline Specifications & $(1.1)$ & $(1.2)$ & $(1.3)$ & $(1.4)$ & $(1.5)$ \\
\hline Number of arrangers & $\begin{array}{c}-0.0185^{* * *} \\
(0.0022)\end{array}$ & & & & \\
\hline Concentration of arrangers & & $\begin{array}{c}-0.2899^{* * *} \\
(0.0768)\end{array}$ & & & \\
\hline Top 10 arrangers (presence) & & & $\begin{array}{c}-0.1556^{* * *} \\
(0.026)\end{array}$ & & \\
\hline Top 10 arrangers (market) & & & & $\begin{array}{c}-0.3731^{* *} \\
(0.1502)\end{array}$ & \\
\hline League table arrangers & & & & & $\begin{array}{c}-0.1164^{* * *} \\
(0.0269)\end{array}$ \\
\hline Loan size & $\begin{array}{c}0.0193^{* *} \\
(0.0098)\end{array}$ & $\begin{array}{c}-0.0291^{* * *} \\
(0.009)\end{array}$ & $\begin{array}{c}-0.0246^{* * *} \\
(0.007)\end{array}$ & $\begin{array}{c}-0.0265^{* * *} \\
(0.0067)\end{array}$ & $\begin{array}{c}-0.0238^{* * *} \\
(0.0067)\end{array}$ \\
\hline Spread & $\begin{array}{c}0.0006^{* *} \\
(0.0003)\end{array}$ & $\begin{array}{l}0.0005 \\
(0.0003)\end{array}$ & $\begin{array}{c}-0.0004^{* *} \\
(0.0002)\end{array}$ & $\begin{array}{c}-0.0005^{* * *} \\
(0.0002)\end{array}$ & $\begin{array}{c}-0.0005^{* * *} \\
(0.0002)\end{array}$ \\
\hline Fee & $\begin{array}{l}-0.0007 \\
(0.0005)\end{array}$ & $\begin{array}{c}-0.0024^{* * *} \\
(0.0006)\end{array}$ & $\begin{array}{c}0.0012^{* * * *} \\
(0.0003)\end{array}$ & $\begin{array}{c}0.0014^{* * *} \\
(0.0004)\end{array}$ & $\begin{array}{c}0.0014^{* * *} \\
(0.0004)\end{array}$ \\
\hline Maturity & $\begin{array}{c}0.0022^{* * *} \\
(0.0006)\end{array}$ & $\begin{array}{c}0.0014^{* * *} \\
(0.0003)\end{array}$ & $\begin{array}{c}0.0004^{* *} \\
(0.0002)\end{array}$ & $\begin{array}{l}0.0002 \\
(0.0002)\end{array}$ & $\begin{array}{c}0.0004^{* *} \\
(0.0002)\end{array}$ \\
\hline Guarantors & $\begin{array}{c}0.0911^{* * * *} \\
(0.0221)\end{array}$ & $\begin{array}{l}0.0088 \\
(0.0287)\end{array}$ & $\begin{array}{l}0.0291^{*} \\
(0.0167)\end{array}$ & $\begin{array}{c}0.0421^{* *} \\
(0.0191)\end{array}$ & $\begin{array}{c}0.0349^{* *} \\
(0.0168)\end{array}$ \\
\hline Covenants & $\begin{array}{c}0.1126^{* * *} \\
(0.0213)\end{array}$ & $\begin{array}{c}0.077^{* * *} \\
(0.0205)\end{array}$ & $\begin{array}{c}0.0677^{* * *} \\
(0.0127)\end{array}$ & $\begin{array}{c}0.0656^{* * *} \\
(0.013)\end{array}$ & $\begin{array}{c}0.0767^{* * *} \\
(0.013)\end{array}$ \\
\hline Senior debt & $\begin{array}{l}0.1199 \\
(0.0821)\end{array}$ & $\begin{array}{c}1.0468^{* * *} \\
(0.0796)\end{array}$ & $\begin{array}{l}-0.1251 \\
(0.0794)\end{array}$ & $\begin{array}{c}-0.2349^{* * *} \\
(0.0657)\end{array}$ & $\begin{array}{c}-0.1375 \\
(0.0858)\end{array}$ \\
\hline $\mathrm{S} \& \mathrm{P}$ rating & $\begin{array}{l}0.2562 \\
(0.471)\end{array}$ & $\begin{array}{c}-0.5874^{* * *} \\
(0.0442)\end{array}$ & $\begin{array}{c}0.0176 \\
(0.04)\end{array}$ & $\begin{array}{c}0.016 \\
(0.0387)\end{array}$ & $\begin{array}{l}0.0376 \\
(0.0363)\end{array}$ \\
\hline Creditor rights & $\begin{array}{c}0.0998^{* * *} \\
(0.0094)\end{array}$ & $\begin{array}{l}0.0109 \\
(0.0214)\end{array}$ & $\begin{array}{c}0.0366^{* * *} \\
(0.0091)\end{array}$ & $\begin{array}{c}0.0359^{* * *} \\
(0.0092)\end{array}$ & $\begin{array}{c}0.0305^{* * *} \\
(0.0093)\end{array}$ \\
\hline Rule of law & $\begin{array}{c}-0.1539^{* * *} \\
(0.0152)\end{array}$ & $\begin{array}{c}0.1661^{* * *} \\
(0.0324)\end{array}$ & $\begin{array}{l}0.0052 \\
(0.0134)\end{array}$ & $\begin{array}{l}-0.0016 \\
(0.0136)\end{array}$ & $\begin{array}{l}-0.0085 \\
(0.0136)\end{array}$ \\
\hline Intercept & $\begin{array}{c}-32.2318^{* * *} \\
(11.3297)\end{array}$ & $\begin{array}{c}-8.3350 \\
(8.5718)\end{array}$ & $\begin{array}{c}-37.9221^{* * *} \\
(7.2874)\end{array}$ & $\begin{array}{c}-27.4776^{* * *} \\
(7.2863)\end{array}$ & $\begin{array}{c}-27.8578^{* * *} \\
(6.8453)\end{array}$ \\
\hline $\mathrm{N}$ & 3274 & 2596 & 3274 & 3274 & 3274 \\
\hline $\mathrm{Chi}^{2}$ & 2171.887 & 6713.32 & 8350.456 & 4377.684 & 6959.042 \\
\hline
\end{tabular}


Table 4: Estimation results with syndicate composition measures only

\begin{tabular}{|c|c|c|c|c|}
\hline Specifications & $(2.1)$ & $(2.2)$ & $(2.3)$ & $(2.4)$ \\
\hline Same country top lenders & $\begin{array}{c}0.1388^{* * *} \\
(0.0275)\end{array}$ & $\begin{array}{c}0.1075^{* * *} \\
(0.0274)\end{array}$ & & \\
\hline Same country mid lenders & & $\begin{array}{c}-0.1055^{* * *} \\
(0.0386)\end{array}$ & & \\
\hline Same country mid-low lenders & & & $\begin{array}{c}-0.0505^{* *} \\
(0.0242)\end{array}$ & \\
\hline Same country top-low lenders & & & & $\begin{array}{l}0.0466 \\
(0.0356)\end{array}$ \\
\hline Loan size & $\begin{array}{c}-0.0232^{* * *} \\
(0.006)\end{array}$ & $\begin{array}{c}-0.0248^{* * *} \\
(0.006)\end{array}$ & $\begin{array}{c}-0.0264^{* * *} \\
(0.0065)\end{array}$ & $\begin{array}{c}-0.0276^{* * *} \\
(0.0064)\end{array}$ \\
\hline Spread & $\begin{array}{c}-0.0004^{* * *} \\
(0.0002)\end{array}$ & $\begin{array}{c}-0.0004^{* * *} \\
(0.0002)\end{array}$ & $\begin{array}{c}-0.0005^{* * *} \\
(0.0002)\end{array}$ & $\begin{array}{c}-0.0005^{* * *} \\
(0.0002)\end{array}$ \\
\hline Fee & $\begin{array}{c}0.0014^{* * *} \\
(0.0003)\end{array}$ & $\begin{array}{c}0.0014^{* * *} \\
(0.0003)\end{array}$ & $\begin{array}{c}0.0014^{* * *} \\
(0.0003)\end{array}$ & $\begin{array}{c}0.0014^{* * *} \\
(0.0003)\end{array}$ \\
\hline Maturity & $\begin{array}{c}0.0005^{* * *} \\
(0.0002)\end{array}$ & $\begin{array}{c}0.0004^{* * *} \\
(0.0002)\end{array}$ & $\begin{array}{c}0.0004^{* * *} \\
(0.0002)\end{array}$ & $\begin{array}{c}0.0004^{* * *} \\
(0.0002)\end{array}$ \\
\hline Guarantors & $\begin{array}{l}0.04^{* *} \\
(0.016)\end{array}$ & $\begin{array}{c}0.0455^{* * *} \\
(0.0159)\end{array}$ & $\begin{array}{c}0.0317^{*} \\
(0.0167)\end{array}$ & $\begin{array}{l}0.0295^{*} \\
(0.0163)\end{array}$ \\
\hline Covenants & $\begin{array}{c}0.0548^{* * *} \\
(0.0133)\end{array}$ & $\begin{array}{c}0.053^{* * *} \\
(0.0133)\end{array}$ & $\begin{array}{c}0.0623^{* * *} \\
\quad(0.013)\end{array}$ & $\begin{array}{c}0.0647^{* * *} \\
(0.0131)\end{array}$ \\
\hline Senior debt & $\begin{array}{c}-0.1403^{* *} \\
(0.0713)\end{array}$ & $\begin{array}{c}-0.1504^{* *} \\
(0.0724)\end{array}$ & $\begin{array}{c}-0.1319^{*} \\
(0.0773)\end{array}$ & $\begin{array}{c}-0.1401^{*} \\
(0.0801)\end{array}$ \\
\hline $\mathrm{S} \& \mathrm{P}$ rating & $\begin{array}{l}0.0141 \\
(0.035)\end{array}$ & $\begin{array}{l}0.0187 \\
(0.0351)\end{array}$ & $\begin{array}{l}0.0235 \\
(0.0371)\end{array}$ & $\begin{array}{c}0.026 \\
(0.0372)\end{array}$ \\
\hline Creditor rights & $\begin{array}{c}0.0418^{* * *} \\
(0.0087)\end{array}$ & $\begin{array}{c}0.0418^{* * * *} \\
(0.0083)\end{array}$ & $\begin{array}{c}0.0373^{* * *} \\
(0.0089)\end{array}$ & $\begin{array}{c}0.0383^{* * *} \\
(0.009)\end{array}$ \\
\hline Rule of law & $\begin{array}{r}0.0153 \\
(0.0137)\end{array}$ & $\begin{array}{r}0.0075 \\
(0.0136)\end{array}$ & $\begin{array}{c}-0.0040 \\
(0.0134)\end{array}$ & $\begin{array}{c}-0.0054 \\
(0.0133)\end{array}$ \\
\hline Intercept & $\begin{array}{c}-27.6439^{* * *} \\
(6.6182)\end{array}$ & $\begin{array}{c}-32.5827^{* * *} \\
(6.9538)\end{array}$ & $\begin{array}{c}-28.1710^{* * *} \\
(6.9599)\end{array}$ & $\begin{array}{c}-28.2415^{* * *} \\
(7.1009)\end{array}$ \\
\hline $\mathrm{N}$ & 3274 & 3274 & 3274 & 3274 \\
\hline $\mathrm{Chi}^{2}$ & 7349.766 & 7970.226 & 7857.641 & 8143.089 \\
\hline
\end{tabular}


Table 5: Estimation results with syndicate size, experience, reputation, and composition measures

The table provides estimation results of the accelerated failure time model with a gamma distribution for different specifications in terms of syndicate organization measures. The dependent variable is Syndication process duration. Definition of variables appear in table 1. Robust standard errors in parentheses. ${ }^{* * *},{ }^{* *},{ }^{*}$ correspond to coefficients significantly different from 0 at 1\%, $5 \%$ and $10 \%$ level. Loan and country characteristics, as well as loan type, loan purpose, benchmark rate, facility active year, industry and geographical areas dummies included but not reported.

\begin{tabular}{|c|c|c|c|c|}
\hline Specifications & $(1.1 \mathrm{a})$ & $(1.1 b)$ & $(1.1 \mathrm{c})$ & $(1.1 d)$ \\
\hline Number of arrangers & $\begin{array}{c}-0.0162^{\text {*** }} \\
(0.0021)\end{array}$ & $\begin{array}{c}-0.0161^{* * *} \\
(0.0021)\end{array}$ & $\begin{array}{c}-0.0170^{* * *} \\
(0.0023)\end{array}$ & $\begin{array}{c}-0.0182^{* * *} \\
(0.0023)\end{array}$ \\
\hline Same country top lenders & $\begin{array}{c}0.2139^{* * *} \\
(0.0397)\end{array}$ & $\begin{array}{c}0.1757^{* * *} \\
(0.0406)\end{array}$ & & \\
\hline Same country mid lenders & & $\begin{array}{c}-0.1955^{* * *} \\
(0.0647)\end{array}$ & & \\
\hline Same country mid-low & & & $\begin{array}{c}-0.2875^{* * *} \\
(0.0425)\end{array}$ & \\
\hline Same country top-low & & & & $\begin{array}{c}0.2843^{* * *} \\
(0.0556)\end{array}$ \\
\hline $\mathrm{N}$ & 3274 & 3274 & 3274 & 3274 \\
\hline $\mathrm{Chi}^{2}$ & 2360.716 & 2473.53 & 2183.467 & 2419.181 \\
\hline Specifications & $(1.3 \mathrm{a})$ & $(1.3 \mathrm{~b})$ & $(1.3 \mathrm{c})$ & $(1.3 \mathrm{~d})$ \\
\hline Top 10 arrangers (presence) & $\begin{array}{c}-0.1218^{* * *} \\
(0.0281)\end{array}$ & $\begin{array}{c}-0.1147^{* * *} \\
(0.0293)\end{array}$ & $\begin{array}{c}-0.1560^{* * *} \\
(0.0283)\end{array}$ & $\begin{array}{c}-0.1537^{* * *} \\
(0.0279)\end{array}$ \\
\hline Same country top lenders & $\begin{array}{c}0.1109^{* * *} \\
(0.0309)\end{array}$ & $\begin{array}{c}0.0864^{* * *} \\
(0.0295)\end{array}$ & & \\
\hline Same country mid lenders & & $\begin{array}{c}-0.0877^{* *} \\
(0.0403)\end{array}$ & & \\
\hline Same country mid-low lenders & & & $\begin{array}{l}0.0011 \\
(0.0267)\end{array}$ & \\
\hline Same country top-low lenders & & & & $\begin{array}{c}0.011 \\
(0.0376)\end{array}$ \\
\hline $\mathrm{N}$ & 3274 & 3274 & 3274 & 3274 \\
\hline $\mathrm{Chi}^{2}$ & 7885.444 & 8439.457 & 8408.059 & 8414.194 \\
\hline
\end{tabular}


Table 5: (continued)

\begin{tabular}{|c|c|c|c|c|}
\hline Specifications & $(1.4 \mathrm{a})$ & $(1.4 \mathrm{~b})$ & $(1.4 \mathrm{c})$ & $(1.4 \mathrm{~d})$ \\
\hline Top 10 arrangers (market) & $\begin{array}{c}-0.3595^{* *} \\
(0.1626)\end{array}$ & $\begin{array}{c}-0.3714^{* *} \\
(0.1718)\end{array}$ & $\begin{array}{c}-0.3707^{* *} \\
(0.152)\end{array}$ & $\begin{array}{c}-0.3807^{* *} \\
(0.1539)\end{array}$ \\
\hline Same country top lenders & $\begin{array}{c}0.1294^{* * *} \\
\quad(0.0298)\end{array}$ & $\begin{array}{c}0.0955^{* * *} \\
(0.031)\end{array}$ & & \\
\hline Same country mid lenders & & $\begin{array}{c}-0.1101^{* * *} \\
(0.0376)\end{array}$ & & \\
\hline Same country mid-low lenders & & & $\begin{array}{c}-0.0455 \\
(0.0444)\end{array}$ & \\
\hline Same country top-low lenders & & & & $\begin{array}{c}0.0528 \\
(0.033)\end{array}$ \\
\hline $\mathrm{N}$ & 3274 & 3274 & 3274 & 3274 \\
\hline $\mathrm{Chi}^{2}$ & 4279.283 & 4509.396 & 4436.914 & 4403.339 \\
\hline Specifications & $(1.5 \mathrm{a})$ & $(1.5 \mathrm{~b})$ & $(1.5 \mathrm{c})$ & $(1.5 \mathrm{~d})$ \\
\hline League table arrangers & $\begin{array}{c}-0.1024^{* * *} \\
(0.0275)\end{array}$ & $\begin{array}{c}-0.0968^{* * *} \\
(0.0278)\end{array}$ & $\begin{array}{c}-0.1116^{* * *} \\
(0.0272)\end{array}$ & $\begin{array}{c}-0.1138^{* * *} \\
(0.027)\end{array}$ \\
\hline Same country top lenders & $\begin{array}{c}0.1298^{* * *} \\
(0.0278)\end{array}$ & $\begin{array}{c}0.1026^{* * *} \\
(0.0276)\end{array}$ & & \\
\hline Same country mid lenders & & $\begin{array}{c}-0.0931^{* *} \\
(0.0385)\end{array}$ & & \\
\hline Same country mid-low lenders & & & $\begin{array}{c}-0.0338 \\
(0.024)\end{array}$ & \\
\hline Same country top-low lenders & & & & $\begin{array}{l}0.0339 \\
(0.0349)\end{array}$ \\
\hline $\mathrm{N}$ & 3274 & 3274 & 3274 & 3274 \\
\hline $\mathrm{Chi}^{2}$ & 6727.139 & 7299.141 & 6997.724 & 7127.783 \\
\hline
\end{tabular}


Table 6: Estimation results with syndicate size, concentration, experience, reputation, and composition measures for borrowers with low reputation

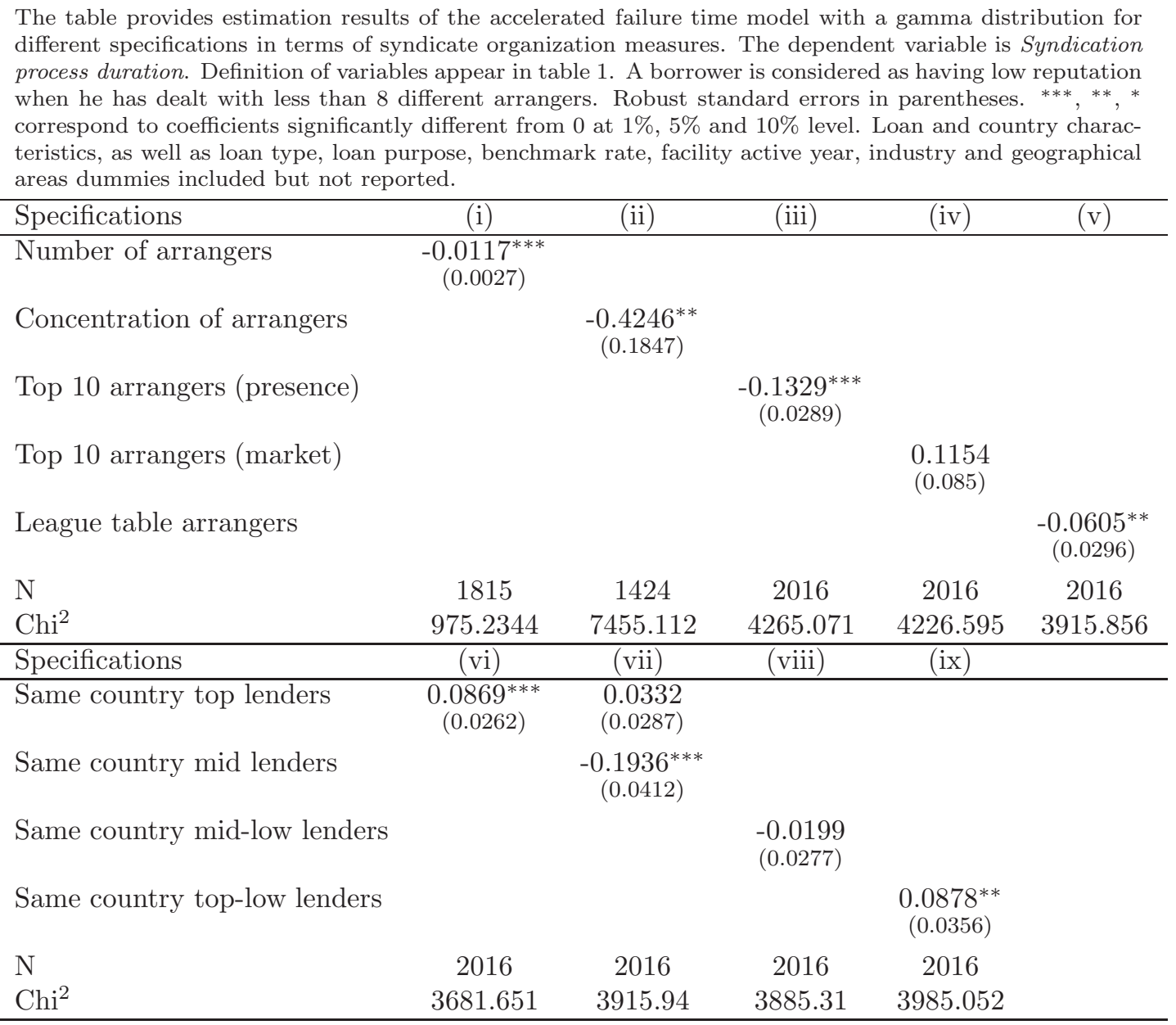


Table 7: Estimation results with syndicate size, concentration, experience, reputation, and composition measures for opaque borrowers

The table provides estimation results of the accelerated failure time model with a gamma distribution for different specifications in terms of syndicate organization measures. The dependent variable is Syndication process duration. Definition of variables appear in table 1. A borrower is considered as opaque when he is not listed on a stock exchange. Robust standard errors in parentheses. ${ }^{* * *},{ }^{* *},{ }^{*}$ correspond to coefficients significantly different from 0 at 1\%, 5\% and 10\% level. Loan and country characteristics, as well as loan type, loan purpose, benchmark rate, facility active year, industry and geographical areas dummies included but not reported.

\begin{tabular}{|c|c|c|c|c|}
\hline Specifications & & (xi) & (xii) & \\
\hline Top 10 arrangers (presence) & $\begin{array}{c}-0.1874^{* * *} \\
(0.0348)\end{array}$ & & & \\
\hline Top 10 arrangers (market) & & $\begin{array}{c}-0.7555^{* * *} \\
(0.2544)\end{array}$ & & \\
\hline League table arrangers & & & $\begin{array}{c}-0.1478^{* * *} \\
(0.0401)\end{array}$ & \\
\hline $\mathrm{N}$ & 2003 & 2003 & 2003 & \\
\hline $\mathrm{Chi}^{2}$ & 6627.354 & 4292.728 & 6179.461 & \\
\hline Specifications & (xiii) & (xiv) & (xv) & (xvi) \\
\hline Same country top lenders & $\begin{array}{c}0.2264^{* * *} \\
(0.0327)\end{array}$ & $\begin{array}{c}0.2095^{* * *} \\
(0.0321)\end{array}$ & & \\
\hline Same country mid lenders & & $\begin{array}{l}-0.0590 \\
(0.0596)\end{array}$ & & \\
\hline Same country mid-low lenders & & & $\begin{array}{c}-0.0696^{*} \\
(0.0403)\end{array}$ & \\
\hline Same country top-low lenders & & & & $\begin{array}{l}0.0226 \\
(0.0557)\end{array}$ \\
\hline $\mathrm{N}$ & 2003 & 2003 & 2003 & 2003 \\
\hline $\mathrm{Chi}^{2}$ & 6157.238 & 6308.005 & 6199.639 & 6218.004 \\
\hline
\end{tabular}




\title{
PAPIERS
}

\section{Laboratoire de Recherche en Gestion \& Economie (LARGE)}

\author{
D.R. $\mathrm{n}^{\circ} 1$ "Bertrand Oligopoly with decreasing returns to scale", \\ J. Thépot, décembre 1993 \\ D.R. $\mathrm{n}^{\circ} 2$ "Sur quelques méthodes d'estimation directe de la structure par terme \\ des taux d'intérêt", P. Roger - N. Rossiensky, janvier 1994 \\ D.R. $\mathrm{n}^{\circ} 3$ "Towards a Monopoly Theory in a Managerial Perspective", \\ J. Thépot, mai 1993 \\ D.R. n 4 "Bounded Rationality in Microeconomics", J. Thépot, mai 1993 \\ D.R. n 5 "Apprentissage Théorique et Expérience Professionnelle", \\ J. Thépot, décembre 1993 \\ D.R. $\mathrm{n}^{\circ} 6 \quad$ "Stratégic Consumers in a Duable-Goods Monopoly", \\ J. Thépot, avril 1994 \\ D.R. n 7 "Vendre ou louer ; un apport de la théorie des jeux", J. Thépot, avril 1994 \\ D.R. $n^{\circ} 8$ "Default Risk Insurance and Incomplete Markets", \\ Ph. Artzner - FF. Delbaen, juin 1994 \\ D.R. $n^{\circ} 9 \quad$ "Les actions à réinvestissement optionnel du dividende", \\ C. Marie-Jeanne - P. Roger, janvier 1995 \\ D.R. $\mathrm{n}^{\circ} 10 \quad$ "Forme optimale des contrats d'assurance en présence de coûts \\ administratifs pour l'assureur", S. Spaeter, février 1995 \\ D.R. n 11 "Une procédure de codage numérique des articles", \\ J. Jeunet, février 1995 \\ D.R. $\mathrm{n}^{\circ} 12$ Stabilité d'un diagnostic concurrentiel fondé sur une approche \\ markovienne du comportement de rachat du consommateur", \\ N. Schall, octobre 1995 \\ D.R. $\mathrm{n}^{\circ} 13$ "A direct proof of the coase conjecture", J. Thépot, octobre 1995 \\ D.R. n 14 "Invitation à la stratégie", J. Thépot, décembre 1995 \\ D.R. n 15 "Charity and economic efficiency", J. Thépot, mai 1996
}


D.R. $\mathrm{n}^{\circ} 16$ "Princing anomalies in financial markets and non linear pricing rules", P. Roger, mars 1996

D.R. n 17 "Non linéarité des coûts de l'assureur, comportement de prudence de l'assuré et contrats optimaux", S. Spaeter, avril 1996

D.R. $n^{\circ} 18$ "La valeur ajoutée d'un partage de risque et l'optimum de Pareto : une note", L. Eeckhoudt - P. Roger, juin 1996

D.R. $\mathrm{n}^{\circ} 19$ "Evaluation of Lot-Sizing Techniques : A robustess and Cost Effectiveness Analysis", J. Jeunet, mars 1996

D.R. n 20 "Entry accommodation with idle capacity", J. Thépot, septembre 1996

D.R. $\mathrm{n}^{\circ} 21$ "Différences culturelles et satisfaction des vendeurs : Une comparaison internationale", E. Vauquois-Mathevet - J.Cl. Usunier, novembre 1996

D.R. n 22 "Evaluation des obligations convertibles et options d'échange", A. Schmitt - F. Home, décembre 1996

D.R n ${ }^{\circ} 23$ "Réduction d'un programme d'optimisation globale des coûts et diminution du temps de calcul, J. Jeunet, décembre 1996

D.R. n 24 "Incertitude, vérifiabilité et observabilité : Une relecture de la théorie de l'agence", J. Thépot, janvier 1997

D.R. $n^{\circ} 25$ "Financement par augmentation de capital avec asymétrie d'information : l'apport du paiement du dividende en actions", C. Marie-Jeanne, février 1997

D.R. $\mathrm{n}^{\circ} 26$ "Paiement du dividende en actions et théorie du signal", C. Marie-Jeanne, février 1997

D.R. n 27 "Risk aversion and the bid-ask spread", L. Eeckhoudt - P. Roger, avril 1997

D.R. n 28 "De l'utilité de la contrainte d'assurance dans les modèles à un risque et à deux risques", S. Spaeter, septembre 1997

D.R. $n^{\circ} 29$ "Robustness and cost-effectiveness of lot-sizing techniques under revised demand forecasts", J. Jeunet, juillet 1997

D.R. n 30 "Efficience du marché et comparaison de produits à l'aide des méthodes d'enveloppe (Data envelopment analysis)", S. Chabi, septembre 1997

D.R. n 31 "Qualités de la main-d'œuvre et subventions à l'emploi : Approche microéconomique", J. Calaza - P. Roger, février 1998

D.R n 32 "Probabilité de défaut et spread de taux : Etude empirique du marché français", M. Merli - P. Roger, février 1998 
D.R. n 33 "Confiance et Performance : La thèse de Fukuyama",

J.Cl. Usunier - P. Roger, avril 1998

D.R. $n^{\circ} 34$ "Measuring the performance of lot-sizing techniques in uncertain environments", J. Jeunet - N. Jonard, janvier 1998

D.R. n 35 "Mobilité et décison de consommation : premiers résultas dans un cadre monopolistique", Ph. Lapp, octobre 1998

D.R. $n^{\circ} 36$ "Impact du paiement du dividende en actions sur le transfert de richesse et la dilution du bénéfice par action", C. Marie-Jeanne, octobre 1998

D.R. n 37 "Maximum resale-price-maintenance as Nash condition", J. Thépot, novembre 1998

D.R. $n^{\circ} 38$ "Properties of bid and ask prices in the rank dependent expected utility model", P. Roger, décembre 1998

D.R. n 39 "Sur la structure par termes des spreads de défaut des obligations », Maxime Merli / Patrick Roger, septembre 1998

D.R. $n^{\circ} 40$ "Le risque de défaut des obligations : un modèle de défaut temporaire de l'émetteur", Maxime Merli, octobre 1998

D.R. n 41 "The Economics of Doping in Sports", Nicolas Eber / Jacques Thépot, février 1999

D.R. $\mathrm{n}^{\circ} 42$ "Solving large unconstrained multilevel lot-sizing problems using a hybrid genetic algorithm", Jully Jeunet, mars 1999

D.R n 43 "Niveau général des taux et spreads de rendement", Maxime Merli, mars 1999

D.R. n 44 "Doping in Sport and Competition Design", Nicolas Eber / Jacques Thépot, septembre 1999

D.R. n 45 "Interactions dans les canaux de distribution", Jacques Thépot, novembre 1999

D.R. n 46 "What sort of balanced scorecard for hospital", Thierry Nobre, novembre 1999

D.R. n 47 "Le contrôle de gestion dans les PME", Thierry Nobre, mars 2000

D.R. $\mathrm{n}^{\circ} 48$ "Stock timing using genetic algorithms", Jerzy Korczak - Patrick Roger, avril 2000

D.R. n 49 "On the long run risk in stocks : A west-side story", Patrick Roger, mai 2000

D.R. n 50 "Estimation des coûts de transaction sur un marché gouverné par les ordres : Le cas des composantes du CAC40", Laurent Deville, avril 2001

D.R. n 51 "Sur une mesure d'efficience relative dans la théorie du portefeuille de Markowitz", Patrick Roger / Maxime Merli, septembre 2001 
D.R. $\mathrm{n}^{\circ} 52$ "Impact de l'introduction du tracker Master Share CAC 40 sur la relation de parité call-put", Laurent Deville, mars 2002

D.R. $\mathrm{n}^{\circ} 53$ "Market-making, inventories and martingale pricing", Patrick Roger / Christian At / Laurent Flochel, mai 2002

D.R. n 54 "Tarification au coût complet en concurrence imparfaite", Jean-Luc Netzer / Jacques Thépot, juillet 2002

D.R. $n^{\circ} 55$ "Is time-diversification efficient for a loss averse investor ?", Patrick Roger, janvier 2003

D.R. n 56 "Dégradations de notations du leader et effets de contagion”, Maxime Merli / Alain Schatt, avril 2003

D.R. n 57 “Subjective evaluation, ambiguity and relational contracts”, Brigitte Godbillon, juillet 2003

D.R. n 58 “A View of the European Union as an Evolving Country Portfolio”, Pierre-Guillaume Méon / Laurent Weill, juillet 2003

D.R. n 59 “Can Mergers in Europe Help Banks Hedge Against Macroeconomic Risk ?”, Pierre-Guillaume Méon / Laurent Weill, septembre 2003

D.R. $n^{\circ} 60 \quad$ "Monetary policy in the presence of asymmetric wage indexation”, Giuseppe Diana / PierreGuillaume Méon, juillet 2003

D.R. n 61 “Concurrence bancaire et taille des conventions de services”, Corentine Le Roy, novembre 2003

D.R. n 62 “Le petit monde du CAC 40”, Sylvie Chabi / Jérôme Maati

D.R. $n^{\circ} 63$ “Are Athletes Different ? An Experimental Study Based on the Ultimatum Game”, Nicolas Eber / Marc Willinger

D.R. n 64 "Le rôle de l'environnement réglementaire, légal et institutionnel dans la défaillance des banques : Le cas des pays émergents”, Christophe Godlewski, janvier 2004

D.R. n 65 "Etude de la cohérence des ratings de banques avec la probabilité de défaillance bancaire dans les pays émergents”, Christophe Godlewski, Mars 2004

D.R. n 66 “Le comportement des étudiants sur le marché du téléphone mobile : Inertie, captivité ou fidélité ?”, Corentine Le Roy, Mai 2004

D.R. $n^{\circ} 67$ "Insurance and Financial Hedging of Oil Pollution Risks", André Schmitt / Sandrine Spaeter, September, 2004

D.R. $n^{\circ} 68$ “On the Backwardness in Macroeconomic Performance of European Socialist Economies”, Laurent Weill, September, 2004 
D.R. $n^{\circ} 69$ "Majority voting with stochastic preferences : The whims of a committee are smaller than the whims of its members”, Pierre-Guillaume Méon, September, 2004

D.R. $n^{\circ} 70 \quad$ "Modélisation de la prévision de défaillance de la banque : Une application aux banques des pays émergents”, Christophe J. Godlewski, octobre 2004

D.R. n 71 "Can bankruptcy law discriminate between heterogeneous firms when information is incomplete ? The case of legal sanctions”, Régis Blazy, october 2004

D.R. n 72 “La performance économique et financière des jeunes entreprises”, Régis Blazy/Bertrand Chopard, octobre 2004

D.R. n 73 “Ex Post Efficiency of bankruptcy procedures : A general normative framework”, Régis Blazy / Bertrand Chopard, novembre 2004

D.R. n 74 “Full cost pricing and organizational structure”, Jacques Thépot, décembre 2004

D.R. $n^{\circ} 75$ "Prices as strategic substitutes in the Hotelling duopoly", Jacques Thépot, décembre 2004

D.R. n 76 "Réflexions sur l'extension récente de la statistique de prix et de production à la santé et à l’enseignement”, Damien Broussolle, mars 2005

D. R. n 77 "Gestion du risque de crédit dans la banque: Information hard, information soft et manipulation ”, Brigitte Godbillon-Camus / Christophe J. Godlewski

D.R. n 78 “Which Optimal Design For LLDAs”, Marie Pfiffelmann

D.R. n 79 “Jensen and Meckling 30 years after : A game theoretic view”, Jacques Thépot

D.R. n 80 “Organisation artistique et dépendance à l'égard des ressources”, Odile Paulus, novembre 2006

D.R. $n^{\circ} 81$ "Does collateral help mitigate adverse selection ? A cross-country analysis", Laurent Weill -Christophe J. Godlewski, novembre 2006

D.R. n 82 "Why do banks ask for collateral and which ones ?”, Régis Blazy - Laurent Weill, décembre 2006

D.R. $n^{\circ} 83$ "The peace of work agreement : The emergence and enforcement of a swiss labour market institution”, D. Broussolle, janvier 2006.

D.R. $n^{\circ} 84$ "The new approach to international trade in services in view of services specificities : Economic and regulation issues”, D. Broussolle, septembre 2006.

D.R. $n^{\circ} 85$ "Does the consciousness of the disposition effect increase the equity premium"?, P. Roger, juin 2007

D.R. n 86 "Les déterminants de la décision de syndication bancaire en France”, Ch. J. Godlewski

D.R. n 87 “Syndicated loans in emerging markets”, Ch. J. Godlewski / L. Weill, mars 2007 
D.R. $n^{\circ} 88$ "Hawks and loves in segmented markets : A formal approach to competitive aggressiveness”, Claude d’Aspremont / R. Dos Santos Ferreira / J. Thépot, mai 2007

D.R. n 89 “On the optimality of the full cost pricing”, J. Thépot, février 2007

D.R. n 90 “SME’s main bank choice and organizational structure : Evidence from France”, H. El Hajj Chehade / L. Vigneron, octobre 2007

D.R n 91 “How to solve St Petersburg Paradox in Rank-Dependent Models”?, M. Pfiffelmann, octobre 2007

D.R. $\mathrm{n}^{\circ} 92$ "Full market opening in the postal services facing the social and territorial cohesion goal in France”, D. Broussolle, novembre 2007

D.R. n²008-01 A behavioural Approach to financial puzzles, M.H. Broihanne, M. Merli, P. Roger, janvier 2008

D.R. $\mathrm{n}^{\circ}$ 2008-02 What drives the arrangement timetable of bank loan syndication ?, Ch. J. Godlewski, février 2008

D.R. n 2008-03 Financial intermediation and macroeconomic efficiency, Y. Kuhry, L. Weill, février 2008

D.R. $n^{\circ}$ 2008-04 The effects of concentration on competition and efficiency : Some evidence from the french audit market, G. Broye, L. Weill, février 2008

D.R. $\mathrm{n}^{\circ}$ 2008-05 Does financial intermediation matter for macroeconomic efficiency?, P.G. Méon, L. Weill, février 2008

D.R. $n^{\circ}$ 2008-06 Is corruption an efficient grease ?, P.G. Méon, L. Weill, février 2008

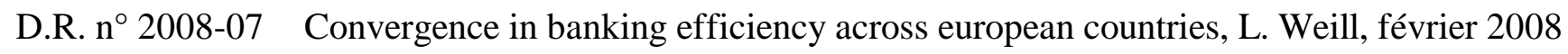

D.R. $\mathrm{n}^{\circ}$ 2008-08 Banking environment, agency costs, and loan syndication : A cross-country analysis, Ch. J. Godlewski, mars 2008

D.R. n 2008-09 Are French individual investors reluctant to realize their losses ?, Sh. Boolell-Gunesh / M.H. Broihanne / M. Merli, avril 2008

D.R. $n^{\circ}$ 2008-10 Collateral and adverse selection in transition countries, Ch. J. Godlewski / L. Weill, avril 2008

D.R. $\mathrm{n}^{\circ}$ 2008-11 How many banks does it take to lend ? Empirical evidence from Europe, Ch. J. Godlewski, avril 2008.

D.R. n 2008-12 Un portrait de l'investisseur individuel français, Sh. Boolell-Gunesh, avril 2008

D.R. n²008-13 La déclaration de mission, une revue de la littérature, Odile Paulus, juin 2008

D.R. n 2008-14 Performance et risque des entreprises appartenant à des groupes de PME, Anaïs Hamelin, juin 2008 
D.R. $n^{\circ}$ 2008-15 Are private banks more efficient than public banks ? Evidence from Russia, Alexei Karas / Koen Schoors / Laurent Weill, septembre 2008

D.R. $n^{\circ}$ 2008-16 Capital protected notes for loss averse investors : A counterintuitive result, Patrick Roger, septembre 2008

D.R. $\mathrm{n}^{\circ}$ 2008-17 Mixed risk aversion and preference for risk disaggregation, Patrick Roger, octobre 2008

D.R. $\mathrm{n}^{\circ}$ 2008-18 Que peut-on attendre de la directive services ?, Damien Broussolle, octobre 2008

D.R. n²008-19 Bank competition and collateral : Theory and Evidence, Christa Hainz / Laurent Weill / Christophe J. Godlewski, octobre 2008. 